\title{
Strategy Eradication Corruption Through Strengthening Legal Instruments
}

\author{
Mohd Yusuf Daeng, ${ }^{1}$ Zulkarnaini, $^{2}$ \& M. Fadli Daeng Yusuf ${ }^{1}$ \\ ${ }^{1}$ Departement Criminal Law, Faculty of Law, University Lancang Kuning, Indonesia \\ ${ }^{2}$ Program Study Public Administration, Faculty Social and Politic, University of Riau, Indonesia \\ *Coresponding Author \\ Email : yf.daeng@yahoo.co.id
}

\begin{abstract}
Corruption crime in Indonesia is widespread in society, its development continues to increase from year to year. This increase occurred both in the number of cases and in the number of state financial losses as well as in terms of quality which were increasingly systematic and in scope that entered all aspects of people's lives. As a result, the title as one of the most corrupt countries in the world has become an unavoidable harsh reality for our nation. The government has tried to fight corruption in various ways. For example, by strengthening existing legal instruments and creating an institution to eradicate corruption. The KPK as an independent institution that specifically handles corruption has become a real effort to prevent and take action against corruption. But on the other hand, enforcement efforts require a lot of money. Not to mention if it is calculated from the impact on the life of society and the state.
\end{abstract}

Keywords: legal instruments, corruption, strategy, KPK

\section{INTRODUCTION}

Corruption in this country is now rampant and has even become a "habit" (Adji, 2006). Various efforts have been made by the government in dealing with corruption and the law is very strict. However, corruption still exists in this country. One of the reasons why people dare to commit criminal acts of corruption is because of a lack of personal awareness about the dangers of corruption. Of course, we can't make the corruptors aware because they are already used to their actions.

Corruption that continues to this day is a serious threat that can endanger the development of life so that the crime of corruption should be categorized as a crime that endangers the welfare of the nation and state (Wiyono, 2005). Efforts to prevent and eradicate corruption in Indonesia need to be carried out seriously, systematically, and in an integrated manner, involving not only the special commission (KPK), but also all institutions (executive, legislative, and judicial) and all members of society, especially the younger generation as successors nation's success (Arif, 2002).

Corruption does not only affect one aspect of life. Corruption causes a widespread domino effect on the existence of the nation and state. The widespread practice of corruption in a country will worsen the economic condition of the nation, for example the price of goods becomes expensive with poor quality, people's access to education and health becomes difficult, the security of a country is threatened, environmental damage, and a bad image of government in the eyes of the international community so that it is destabilizing. the foundations of the trust of foreign capital owners, a prolonged economic crisis, and the country has become increasingly mired in poverty.

One way to prevent corruption is to require public officials to report and announce the amount of wealth they have both before and after taking office (Klitgaard, 2005). Thus, the public can monitor the level of reasonableness of the increase in the amount of wealth they have, especially if there is an increase in the amount of wealth after completing office. 
Difficulties arise when the wealth obtained by committing corruption is transferred to another person, such as a family member.

In addition to the recruitment system, a civil servant performance appraisal system that focuses on process and results needs to be developed (Setiawan, 2008). To improve the work culture and work motivation of civil servants, it is necessary to provide positive incentives for outstanding civil servants (Lubis, 2005). Praise from superiors, awards, bonuses or other types of incentives can spur the performance of civil servants. Of course, this provision must be accompanied by various strict pre-conditions because this also has the potential for corruption, because one-of-a-kind this is actually used as an arena for distribution of bonuses among civil servants.

\section{RESEARCH METHODS}

This study uses legal analysis and evaluation which is defined as an effort to find out the actual situation of the existing legal conditions in order to provide an assessment to find out whether the purpose of its formation has been achieved, as well as to know the benefits and impacts of implementing the legal norms (Ibrahim, 2006). Legal analysis and evaluation is basically part of the legal norm control mechanism. The mechanism of legal control by the judiciary is carried out through "judicial review" and by the legislature through "legislative control" or "legislative review". Meanwhile, the control mechanism carried out by administrative institutions is carried out through "administrative control" or "executive review".

\section{RESULTS AND DISCUSSION}

President Joko Widodo has signed Presidential Regulation Number 54 of 2018 concerning the National Strategy for Corruption Prevention. With the issuance of Presidential Decree 54/2018, Presidential Decree No. 55 of 2012 concerning the National Strategy for Long-Term Prevention and Eradication of Corruption in 2012-2025 and Medium-Term for 2012-2014 is declared no longer valid. As stated in Article 3 of Presidential Regulation $54 / 2018$, that the focus of the national strategy for preventing corruption includes three things. Namely, licensing and trading system; state finances; and law enforcement and bureaucratic reform. "The focus of Stranas PK (National Strategy for Corruption Prevention) as referred to in paragraph (1) is described through PK Action," reads Article 3 paragraph (2) of the Presidential Regulation.

The Presidential Regulation states that licensing and trading systems are the focus because these two things are in direct contact with the community and business actors. The government considers that corruption in the licensing sector can hinder the ease of doing business and investment, economic growth and employment. Meanwhile, corruption in the trade system sector has an impact on high economic costs for basic commodities, so that it becomes a burden, especially for people from economically weak groups. In the licensing and trading sector, there are challenges that can be faced.

The challenge is, there are too many regulations governing licensing authority; the authority to issue permits has not been fully delegated from technical agencies to PTSP both at the central and regional levels; the same licensing service standards have not been implemented in all regions; the limited involvement of the community in supervising licensing at the central and regional levels; strengthening of cartel and monopoly practices in the strategic sector of 
trade in agriculture, plantation, forestry, marine and energy; low involvement of business actors in preventing corruption; and the undeveloped culture of preventing corruption in the private sector (Wahyuningsih dan Martitah, 2014).

The second focus is on state finances. In the Presidential Regulation, it is stated that the management of state finances in principle involves two main sides, namely revenue and expenditure. The reason for corruption on the side of state revenue is the focus because it has an impact on not achieving the target of state revenue and public services and development are not optimal and not on target. Meanwhile, corruption is on the expenditure side, especially in the planning, budgeting, procurement of government goods and services. If prevention is not carried out, it will have an impact on not achieving national development targets.

Challenges in this focus include the persistence of fraud and criminalization of officers in the tax and non-tax sectors; not yet optimal cooperation in the exchange of financial data and taxation; not yet integrated policies, planning processes, budgeting and realization of state expenditures; procurement of goods and services has not been independent and supported by professional human resources; and the limited involvement of the public in the supervision of state financial management at the central and regional levels (Bosu, 2004).

While the third focus is law enforcement and bureaucratic reform because both greatly affect the level of public trust in the state (Napitupulu, 2010). Challenges in this focus include, among others, the lack of optimal coordination of law enforcement officers in handling cases, particularly the exchange of information and data across law enforcement officers; the still weak adaptation of the law enforcement process in the digital era with increasingly developing and complex modes of crime; There are still irregularities in law enforcement.

Then, the weak independence of supervision and internal control of the government, inspectorates at ministries, institutions and local governments; weak supervision of the merit system in the management of the State Civil Apparatus (ASN), uneven quality of information disclosure and public participation in the supervision of public services; and the system for monitoring development and utilization of programs and village development has not been integrated yet. In essence, eradicating corruption requires a common understanding of the criminal act of corruption itself. With the same perception, the eradication of corruption can be carried out in a precise and targeted manner. In order for eradication to be more effective, the three strategies should be carried out simultaneously.

It is very important to link the strategy or efforts to eradicate corruption by looking at the characteristics of the various parties involved and the environment in which they work or operate. There is no single answer, concept or program for every country or organization. There are so many strategies, methods or efforts, all of which must be adapted to the context, society and organization in question. Every country, society and organization must find their own way to find the solution.

One way to eradicate corruption is to establish an independent institution that specifically deals with corruption. For example, in some countries an institution called the Ombudsman has been established. This institution was first established by the Swedish Parliament under the name Justitieombudsmannen in 1809. The role of the ombudsman institution, which later developed in other countries, was to provide facilities for the public who wanted to complain about what was done by Government Institutions and their employees. In addition, this institution also provides education to the government and the community with full integrity.

Indonesia already has an institution specifically formed to eradicate corruption (Djaja, 2009). The institution is the Corruption Eradication Commission (KPK). But with the existence of this institution, will corruption be reduced? Why are there some countries that do not have a special institution that has the authority like the KPK, but the level of corruption in these 
countries is very low? One of the answers is because their judiciary is functioning well and law enforcement officers work with integrity.

Therefore, the thing that needs to be considered is improving the performance of the judiciary, both at the level of the police, prosecutors, courts and correctional institutions (Hamzah, 2005). Courts are the heart of law enforcement, which must be impartial, honest and fair. Many corruption cases are not ensnared by the law because of the very poor performance of the judiciary (Marpaung, 2001). If the performance is poor because it is not capable (unable), it may still be understandable. This means that the knowledge and skills of law enforcement officers must be improved. The problem is if they are unwilling or do not have a strong political will to eradicate corruption, or are involved in various corruption cases.

Bureaucratic reform and public service reform is one way to prevent corruption. The more desks that must be passed to take care of something, the more the possibility for corruption to occur. One way to avoid the practice of bribing bribes in the context of public services is to officially announce the costs that must be incurred by someone to take care of things such as taking care of a passport, obtaining a driving license, taking care of a business license or a building permit (IMB) and so on.

To support the prevention and eradication of corruption, it is not enough to rely on only one legal instrument, namely the Corruption Eradication Law (Ahmad dan Chaerudin, 2008). Various laws and regulations or other legal instruments need to be developed. One of the laws and regulations that must exist to support the eradication of corruption is the Money Laundering Law. To protect witnesses and victims of corruption, a legal instrument is needed in the form of the Law on the Protection of Witnesses and Victims. To empower the press, we need a law that regulates a free press. The mechanism by which the public will report corruption and the use of electronic surveillance also needs to be regulated so as not to violate someone's privacy.

In addition, the right of citizens to freely express their opinions must also be regulated (Danil, 2014). Articles that criminalize the actions of a person who will report a criminal act of corruption and hinder the investigation, investigation and examination of criminal acts of corruption such as articles regarding slander or defamation need to be reviewed and if necessary amended or abolished. It aims to further empower the community (Asshidiqie, 2006). The public should not be afraid to report cases of corruption they know. In addition, to support clean governance, it is necessary to have a Code of Ethics instrument or code of conduct that is intended for all public officials, both executive, legislative and code of conduct for judicial officers (police, prosecutors and courts)

\section{CONCLUSION}

Corruption is like a malignant cancer, which is not only chronic but also acute, eroding the economy of a country slowly but surely. This disease sticks to all aspects of people's lives so it is very difficult to eradicate. For a corruption eradication strategy to be successful, it is important to strengthen legal instruments. To support the prevention and eradication of corruption, it is not enough to rely on only one legal instrument, namely the Corruption Eradication Law. Various laws and regulations or other legal instruments need to be developed. One of the laws and regulations that must exist to support the eradication of corruption is the Money Laundering Law. 


\section{REFERENCES}

Adji, Indriyanto Seno, 2006. Korupsi Kebijakan Aparatur Negara dan Hukum Pidana, Jakarta: C.V. Diadit Media

Ahmad, Dinar Syaiful dan Syarif Fadillah Chaerudin, 2008. Strategi Pencegahan dan Penegakan Hukum Tindak Pidana Korupsi, Bandung: Refika Aditama

Arif, Barda Nawawi, 2002. Bunga Rampai Kebijakan Hukum Pidana, Bandung: Citra Aditya Bakti

Asshidiqie, Jimly, 2006. Hukum Acara Pengujian Undang-Undang, Jakarta: Sekretariat Jenderal dan Kepaniteraan Mahkamah Konstitusi Republik Indonesia

Bosu, Benektiktus, 2004. Menuju Indonesia Baru: Strategi Pemberantasan Tindak Pidana Korupsi, Malang: Bayu Media Publishing

Danil, Elwi 2014. Korupsi: Konsep, Tindak Pidana dan Pemberantasannya, Jakarta: Raja Grafindo Persada

Djaja, Ermansyah, 2009. Memberantas Korupsi Bersama KPK, Jakarta: Sinar Grafika

Hamzah, Andi, 2005. Pemberantasan Korupsi Melalui Hukum Pidana Nasional dan Internasional, Jakarta: Raja Grafindo Persada

Ibrahim, Johny, 2006. Teori dan Metodelogi Hukum Normatif, Malang: Bayu Media Publishing

Klitgaard, Robert, 2005. Membasmi Korupsi (Controlling Corruption), Jakarta: Yayasan Obor Indonesia

Lubis, Todung Mulya, 2005. "Memerangi Korupsi di Peradilan Dari Sisi Advokat", Makalah pada Seminar Anti Corruption Summit diselenggarakan oleh Fakultas Hukum Universitas Gajah Mada Yogyakarta, 11-12 Agustus 2005

Marpaung, Leden, 2001. Tindak Pidana Korupsi: Pemberantasan dan Pencegahan, Jakarta: Bina Grafika

Napitupulu, Diana, 2010. KPK in Action, Jakarta: Raih Asa Sukses

Setiawan, Deni, 2008, KPK Memburu Koruptor, Jakarta: Pustaka Timur

Wahyuningsih, Sri Endah dan Martitah. 2014. "Kebijakan Hukum Pidana dalam Pemberantasan

Tindak Pidana Korupsi di Indonesia" Makalah pada Seminar Nasional. Pemberantasan Korupsi di Indonesia. Semarang: DPP IKA Universitas Negeri Semarang

Wiyono, R., 2005. Pembahasan Undang-Undang Pemberantasan Tindak Pidana Korupsi, Jakarta: Sinar Grafika 